\title{
Bacterial Resistance
}

\section{Ricardo Ferraz ${ }^{1,2^{*}}$, Cristina Prudêncio ${ }^{1,3}$, Mónica Vieira', Rúben Fernandes ${ }^{1,3}$, João Paulo Noronha² and Zeljko Petrovski²}

${ }^{1}$ Center for Health Research and Environment, School of Health Technology, Polytechnic Institute of Porto Porto, Rua Perfect Valente, \# 322,4400 -330, Vila Nova de Gaia, Portugal

${ }^{2}$ Department of Chemistry, REQUIMTE, Faculty of Science and Technology, New University of Lisbon, Caparica, Portugal

${ }^{3}$ Center of Pharmacology and Chemical Biopathology (U38-FCT), Faculty of Medicine, University of Porto, Portugal

Nowadays, bacterial resistance to the different antibiotics is a major public health problem [1-4]. Recent outbreaks, like the one found in Germany for E. coli O104 [5,6] as well as the emergence of multidrug resistant organisms, such as gram-negative Enterobacteriaceae associated to the New Delhi metallo $\beta$-lactamase [7-9] evidence this problem $[4,10-12]$, that not only has public health implications, but also at an economic and social level, threatening global safety $[13,14]$. The latest studies reported also the significant financial burden on health care-associated infections (HAIs) in the USA $[15,16]$. In the UK, approximately $9 \%$ of hospitalized patients acquire an infection after post-admission to hospital which increases the budget in the health care system $[15,17]$.

Until approximately 1960, scientists produced and developed more, than 20 new classes of antibiotics. Since then, only two new classes of antibiotics have appeared [18]. The problem of resistance presented by bacteria is well known for approximately 20 years or more but pharmaceutical industry does not invest in development of new antibiotics [18]. This may be due to the fact that the period necessary for bacteria to develop resistance is becoming shorter [19], and consequently increases the challenges that pharmaceutical industry faces [20]. Instead of developing new antimicrobial agents that prove to be more expensive and unsuccessful [19], scientific community opt for another approach - modification of existing antimicrobial agents and further studies $[19,21]$.

This could lead to the use of non-antibiotics compounds that have antimicrobial properties [21,22]. These molecules could act through a new mechanism, or may interfere with the developed resistance mechanism, and could revert the resistance phenotype, previously presented. In the last case, for example, the mechanism of action may be: an alteration of membrane permeability to antibiotics [22], inhibition of efflux pumps [23], or the inhibition of beta-lactamases, when the resistance mechanism is present.

In this context, it is important to know and study the resistance mechanisms, and also study non-antibiotics compounds as antimicrobial agents.

\section{References}

1. Ferraz R, Branco LC, Marrucho IM, Araujo JMM, Rebelo LPN, et al. (2012) Development of Novel Ionic Liquids-APIs based on Ampicillin. MedChemComm.

2. Amador P, Fernandes R, Brito L, Prudencio C (2011) Antibiotic resistance in Enterobacteriaceae isolated from portuguese deli meats. Journal of Food Safety 31: 1-20.

3. Amador P, Fernandes R, Duarte I, Brito L, Prudencio C (2011) In vitro transference and molecular characterization of bla $_{\text {ТЕM }}$ genes in bacteria isolated from Portuguese ready-to-eat foods. World J Microbiol Biotechnol 27: 17751785.

4. Fernandes R, Prudencio C (2010) Post-surgical wound infections involving Enterobacteriaceae with reduced susceptibility to $\beta$-lactams in two Portuguese hospitals. Int Wound J 7: 508-514

5. Pennington H (2011) Escherichia coli O104, Germany 2011. Lancet Infect Dis 11: 652-653.

6. Bielaszewska M, Mellmann A, Zhang W, Koeck R, Fruth A, et al. (2011)
Characterisation of the Escherichia coli strain associated with an outbreak of haemolytic uraemic syndrome in Germany, 2011: a microbiological study. Lancet Infect Dis 11: 671-676.

7. Tseng SH, Lee CM, Lin TY, Chang SC, Chang FY (2011) Emergence and spread of multi-drug resistant organisms: think globally and act locally. J Microbiol Immunol Infect 44: 157-165.

8. Kumarasamy KK, Toleman MA, Walsh TR, Bagaria J, Butt F, et al. (2010) Emergence of a new antibiotic resistance mechanism in India, Pakistan, and the UK: a molecular, biological, and epidemiological study. Lancet Infect Dis 10: $597-602$

9. Mochon AB, Garner OB, Hindler JA, Krogstad P, Ward KW, et al. (2011) New Delhi Metallo-beta-Lactamase (NDM-1)-Producing Klebsiella pneumoniae: Case Report and Laboratory Detection Strategies. Journal of Clinical Microbiology 49: 2386.

10. Amador P, Fernandes R, Prudencio C, Brito L (2009) Resistance to Betalactams in Bacteria Isolated from Different Types of Portuguese Cheese. Int J Mol Sci 10: 1538-1551.

11. Fernandes R, Vieira M, Ferraz R, Prudencio C (2008) Bloodstream infections caused by multidrug-resistant Enterobacteriaceae: report from two Portuguese hospitals. J Hosp Infect 70: 93-95.

12. Fernandes R, Gestoso A, Freitas JM, Santos P, Prudencio C (2009) High resistance to fourth-generation cephalosporins among clinical isolates of Enterobacteriaceae producing extended-spectrum beta-lactamases isolated in Portugal. Int J Antimicrob Agents 33: 184-185.

13. zur Wiesch PA, Kouyos R, Engelstaedter J, Regoes RR, Bonhoeffer S (2011) Population biological principles of drug-resistance evolution in infectious diseases. Lancet Infect Dis 11: 236-247.

14. Albrich WC, Harbarth S (2008) Health-care workers: source, vector, or victim of MRSA? Lancet Infect Dis 8: 289-301.

15. Busetti A, Crawford DE, Earle MJ, Gilea MA, Gilmore BF, et al. (2010) Antimicrobial and antibiofilm activities of 1-alkylquinolinium bromide ionic liquids. Green Chem 12: 420-425.

16. Scott II RD (2009) The direct medical costs of Healthcare-Associated Infections in U.S. Hospitals, and benefits of prevention. USA: Centers for Disease Contro and Prevention.

17. Plowman R, Graves N, Griffin MA, Roberts JA, Swan AV, et al. (2001) The rate and cost of hospital-acquired infections occurring in patients admitted to selected specialties of a district general hospital in England and the nationa burden imposed. J Hosp Infect 47: 198-209.

18. Coates AR, Halls G, Hu Y (2011) Novel classes of antibiotics or more of the same? Br J Pharmacol 163: 184-94.

*Corresponding author: Ricardo Ferraz, Center for Health Research and Environment, School of Health Technology, Polytechnic Institute of Porto Porto, Rua Perfect Valente, \# 322, 4400-330, Vila Nova de Gaia, Portugal, Email: ricardoferraz@eu.ipp.pt

Received November 21, 2012; Accepted November 23, 2012; Published November 26, 2012

Citation: Ferraz R, Prudêncio C, Vieira M, Fernandes R, Noronha JP, et al. (2012) Bacterial Resistance. Biochem Pharmacol 1:e138. doi:10.4172/2167 $0501.1000 \mathrm{e} 138$

Copyright: ( 2012 Ferraz R, et al. This is an open-access article distributed unde the terms of the Creative Commons Attribution License, which permits unrestricted use, distribution, and reproduction in any medium, provided the original author and source are credited. 
Citation: Ferraz R, Prudêncio C, Vieira M, Fernandes R, Noronha JP, et al. (2012) Bacterial Resistance. Biochem Pharmacol 1:e139. doi:10.4172/21670501.1000 e138

Page 2 of 2

19. Schwarz S, Kehrenberg C (2006) Old dogs that learn new tricks: Modified antimicrobial agents that escape pre-existing resistance mechanisms. Int $J$ Med Microbiol 296: 45-49.

20. Ferraz R, Branco LC, Prudencio C, Noronha JP, Petrovski Z (2011) Ionic Liquids as Active Pharmaceutical Ingredients. ChemMedChem 6: 975-985.

21. Martins M, Dastidar SG, Fanning S, Kristiansen JE, Molnar J, et al. (2008) Potential role of non-antibiotics (helper compounds) in the treatment of multidrug-resistant Gram-negative infections: mechanisms for their direct and indirect activities. Int J Antimicrob Agents 31: 198-208.

22. El-Nakeeb MA, Abou-Shleib HM, Khalil AM, Omar HG, El-Halfawy OM (2012) Reversal of antibiotic resistance in Gram-positive bacteria by the antihistaminic azelastine. APMIS 120: 215-220.

23. Prudencio C, Sansonetty F, Sousa MJ, Corte-Real M, Leao C (2000) Rapid detection of efflux pumps and their relation with drug resistance in yeast cells. Cytometry 39: 26-35. 